\title{
Linkage investigations in two families with hereditary ataxia
}

\author{
J VAN ROSSUM, * H VEENEMA, $†$ AND L N WENT $\dagger$ \\ From the Department of Neurology, University Hospital, Leyden* and the \\ Department of Human Genetics, Sylvius Laboratories, State University, Leyden $\dagger$
}

S U M MARY In two families with autosomal dominant olivopontocerebellar atrophy (type IV), 15 affected and 44 unaffected members were typed for 28 genetic markers, including HLA. The lod scores for a possible HLA linkage, plotted against recombination fractions from 0.01 to 0.4 , were negative. No evidence emerged for the presence of the ataxia-locus within measurable distance of the HLA-loci on chromosome 6. No indications were obtained that the ataxia-gene is linked with one of the other marker-genes.

In the search for laboratory tests to predict the risk for persons in families with dominantly inherited ataxia, the presence of close linkage of the ataxia locus with the HLA loci on the sixth chromosome has been suggested by some investigators. $^{12}$ The evidence of others ${ }^{3-6}$ has been less convincing. Some found no evidence of linkage. ${ }^{7-8}$ Clearly, the question of linkage between the HLA loci and a dominantly inherited ataxia locus has not so far been solved. Two points must be kept in mind in analysing conflicting data: (a) the possible existence of genetic heterogeneity, different loci being responsible for clinically identical forms of ataxia, and (b) the relatively late age at onset of the disease.

Recently, we had the opportunity to study two families with a dominant ataxia, and were able to perform typing for 28 genetic markers including HLA in 59 affected and unaffected members.

\section{Material and methods}

In the two families studied, slowly progressive ataxia becomes manifest at the adult age. A pedigree study back to 1843 did not disclose a relationship between the two families. The clinical picture within both families A and B is identical. Family $B$ lives in the same rural area in Holland from where a man and some of his daughters emigrated to the United States in 1866 where they developed hereditary ataxia, as

Address for reprint requests: Dr van Rossum, Department of Neurology, University Hospital, Leyden, The Netherlands.

Accepted 10 March 1981 described extensively by Schut. ${ }^{910}$ A relationship between family $B$ and the family reported by Schut has not as yet been established. In family A 34 persons in two generations, and in family B 25 persons in three generations were examined neurologically. As a rule, the disease starts in the third decade with a slowly progressive ataxia of gait, confining most patients to a wheelchair within ten years. Concurrently, a severe truncal ataxia and a slurred speech become manifest; dysphagia and complete dependency develop in the ultimate stages. All patients show ataxic eye pursuit movements at a rather early stage. Skeletal abnormalities have not been noted except in one affected individual with pes cavus. Although mental deterioration does not occur, mild mental retardation was present in three patients. Abnormality of muscle tone, reflexes and posterior column sensation showed considerable inter-individual differences (table 1). The diagnosis was posed of olivopontocerebellar atrophy type IV (Konigsmark and Weiner). ${ }^{11}$ The necropsy findings of one patient of family A support this diagnosis. ${ }^{12}$

In family $A$ (fig 1 ) the second generation consisted of 10 individuals, six of whom developed ataxia. Their mean age at death was 52 years. These six had 26 children; one died at age 10 years from leukaemia (III-12) and in another non-paternity was established (III-25). Of the remaining 24 children 11 became affected; their first symptoms developed between 25 and 37 years of age except in two where the disease became manifest at the ages of 12 and 15 years (III-11 and III-26), and death occurred at the ages of 34 and 26 years respectively. In the pedigree (fig 1) the appearance of ataxia in three generations and the proportion of ataxic to healthy individuals must be the result of autosomal dominant inheritance. 
Table 1 Additional clinical findings in ataxic individuals

\begin{tabular}{|c|c|c|c|c|c|c|c|c|c|}
\hline Family $A$ & $\begin{array}{l}\text { Age of } \\
\text { onset* }\end{array}$ & $\begin{array}{l}\text { Age at } \\
\text { examination }\end{array}$ & $\begin{array}{l}\text { Head } \\
\text { tremor }\end{array}$ & Tone & $\begin{array}{l}\text { Unsupported } \\
\text { gait }\end{array}$ & $\begin{array}{l}\text { Tendon } \\
\text { reflexes }\end{array}$ & Toe sign & $\begin{array}{l}\text { Posterior column } \\
\text { sensation }\end{array}$ & Miscellaneous \\
\hline III-2 & 25 & 47 & - & Normal & Not possible & $\begin{array}{l}\text { Arms: } \uparrow \\
\text { Legs: } \downarrow\end{array}$ & Equivocal & Normal & Vertical gaze palsy \\
\hline $\begin{array}{l}\text { III-5 } \\
\text { III-9 }\end{array}$ & $\begin{array}{l}20-30 \\
34\end{array}$ & $\begin{array}{l}46 \\
42\end{array}$ & $\overline{+}$ & $\begin{array}{l}\text { Increased } \\
\text { Increased }\end{array}$ & $\begin{array}{l}\text { Not possible } \\
\text { Not possible }\end{array}$ & $\begin{array}{l}\text { Normal } \\
\text { APR -I- }\end{array}$ & $\begin{array}{l}\text { Equivocal } \\
\text { Equivocal }\end{array}$ & $\begin{array}{l}\text { Normal } \\
\text { Normal }\end{array}$ & $\begin{array}{l}\text { Vertical gaze palsy } \\
\text { Orthostatic } \\
\text { hypotension }\end{array}$ \\
\hline III-16 & 34 & 44 & - & Increased & Ataxic & Normal & Babinski & Normal & Pes cavus \\
\hline III-18 & 28 & 46 & - & Normal & Not possible & Increased & Babinski & Normal & Muscles painful \\
\hline I II-22 & 28 & 38 & - & Increased & Ataxic & Normal & Babinski & Normal & $\begin{array}{l}\text { Mentally retarded } \\
\text { (mildly) }\end{array}$ \\
\hline III-23 & 30 & 39 & - & Decreased & Ataxic & Increased & Equivocal & Distal absent & 一 \\
\hline III-24 & 26 & 36 & - & Normal & Not possible & Normal & Babisnski & Distal absent & - \\
\hline \multicolumn{10}{|l|}{ Family $B$} \\
\hline II-6 & 25 & 56 & + & Normal & Not possible & Increased & Babinski & Normal & - \\
\hline II-9 & 28 & 49 & - & Normal & Not possible & APR - $1-$ & Babinski & Distal absent & - \\
\hline II-10 & 25 & 46 & - & Increased & Not possible & Increased & Babinski & Distal absent & 一 \\
\hline II-II & 37 & 44 & - & Normal & Ataxic & Increased & Babinski & Normal & - \\
\hline III-1 & 16 & 34 & + & Normal & Not possible & Absent & Babinski & Normal & $\begin{array}{l}\text { Mentally retarded } \\
\text { (mildly) }\end{array}$ \\
\hline I I I-5 & $? \dagger$ & 25 & - & Normal & Ataxic & Normal & Equivocal & Normal & $\begin{array}{l}\text { Mentally retarded } \\
\text { (mildly) }\end{array}$ \\
\hline
\end{tabular}

* This is an approximation as the first walking difficulties tend to be neglected.

+ Individual not aware of his ataxia at the time of examination.

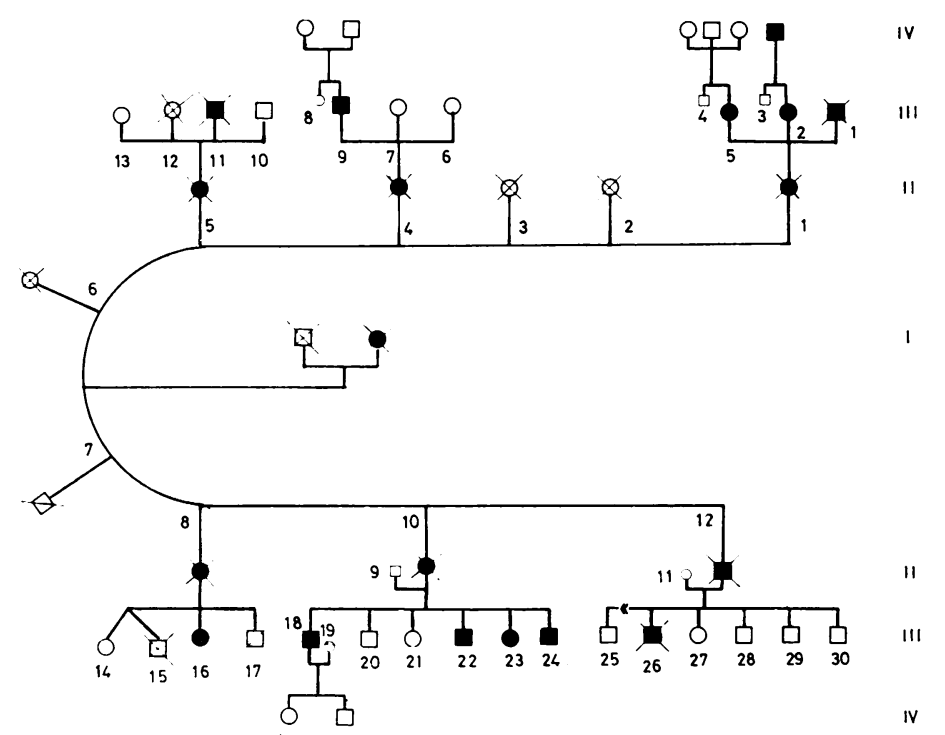

Fig 1 Pedigree of family $A$.

$\bigcirc \square$ Normal (female, male)

Affected

$\circlearrowleft \square$ Not investigated

$\varnothing \boxminus$ Decensed

All living members were examined with the exception of III-17. In two of the sibships the unaffected parent could be investigated. In generation IV we examined eight subjects between 10 and 28 years old (mean 18 years). Only one showed ataxia at age 24 years, of rather recent origin. The other members of this generation are at risk but too young to exclude the presence of the abnormal gene.

In family $B$ (fig 2 ) the investigation included 25 members. No unequivocal history of ataxic symptoms was obtained for either of the parents in generation $I$. The mother died at the age of 80 years and was 


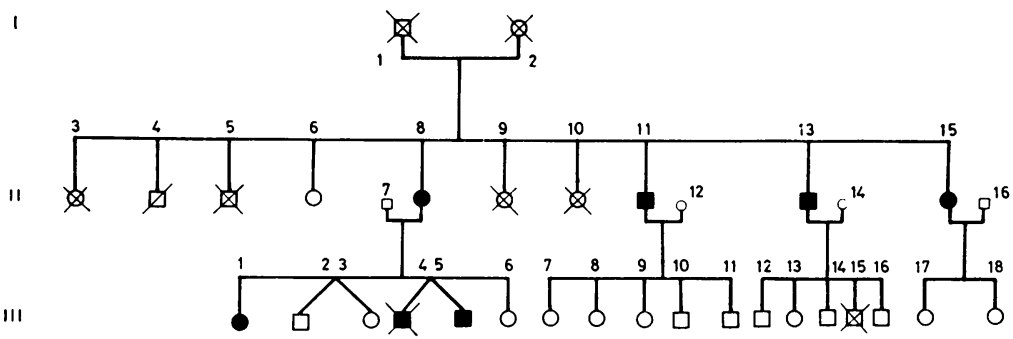

Fig 2 Pedigree of family $B$. For symbols used see fig 1.

said to have been unable to walk since age 72 because of "spinal cord disease." The father died at age 52 years from bronchial cancer. Three of their children died young, three others did not show any symptoms of ataxia as late as their sixties. Four children were disabled because of ataxia, appearing between the ages of 25 and 37 years. The disease has become manifest only in one third generation sibship up to the present day: three out of six sibs developed symptoms of the disease at the age of 13,16 and 23 years respectively. The mean age of the three remaining and as yet unaffected sibs was 28 years. In the other three sibships there are 11 members in generation III between 13 and 26 years. We consider them too young to be identified as either affected or unaffected.

From the 59 affected and unaffected members of both families blood was sampled and taken to the laboratories within 18 hours. For HLA A, B, C and Dr typing standard procedures of the microlymphocytotoxicity tests were used. To explore a possible linkage of the ataxia locus with other genes a number of known genetic markers were investigated. As serum markers were used pseudocholinesterase-2 (E2), transferrine (TF), complement factor (C3), alpha-l-antitrypsin (PI), haptoglobin (HP) and group specific component (GC). Red cell enzymes were typed acid phosphatase (ACP), adenosine deaminase (ADA), adenylate kinase (AK), glutamicpyruvic transaminase (GPT), 6 phosphogluconate dehydrogenase (6PGD), phosphoglucomutase (PGM1), diaphorase (DIAB), esterase (ESD), glyoxalase (GLO) and superoxide dismutase (SOD). Blood groups investigated were ABO, MNS, $P$, Lutheran (Lu), Rhesus, Kell (K), Duffy (Fy) and Kidd (JK); and for markers of immunoglobulins $\mathrm{Gm}, \mathrm{A} 2 \mathrm{~m}$ and $\mathrm{Km}$ were investigated.

HLA specificities were determined in the Department of Immunohaematology, Leyden (Mrs Ir GMTh Schreuder, Prof Dr JJ van Rood).

Serum markers were typed in the Department of Human Genetics, Leyden (Prof Dr LF Bernini).

Red cell ezymes were typed in the Department of Human Genetics, Leyden (Mr H Rijken, Mrs AC Ebeli-Struyk and Mrs LMM Blankenstein-Wijnen).

Blood group systems were determined in the "Centraal Laboratorium van de Bloedtransfusiedienst," Amsterdam (Prof Dr LE Nijenhuis).

Immunoglobulins were typed in the "Centraal
Laboratorium van de Bloedtransfusiedienst," Amsterdam (Dr E van Loghem).

\section{Results}

The results of typing HLA are presented in figs 3 (family A) and 4 (family B). In family A deduction of HLA genotypes in II-10 and II-12 is possible since those of their children and partners were determined. Four of the six children of II-10 were affected, and three out of these four inherited A2B7 from their mother, while this haplotype was found in one of the two unaffected children. If linkage of the ataxia gene with the HLA loci on chromosome 6 were to exist, the A2B7 haplotype in II-10 and her children could be involved. Calculation of non-recombinants (nr) and recombinants (r) leads to $4 \mathrm{nr}$ to $2 \mathrm{r}$. In this way we calculated the total number of non-recombinants and recombinants in both families under different suppositions of linkage of the ataxia locus with a given haplotype. Such a supposition implies that the frequency of recombinants is estimated under the assumption that the parents "phase" is known. Thus the lod score can be estimated as instructed by Maynard-Smith, Penrose and Smith. ${ }^{13}$ For this we calculate the probability of finding the observed distribution of genotypes in a family as a result of linkage at a given distance on the same chromosome, and divide this by the probability of finding the same distribution as a result of chance from unlinked genes (that is $50 \%$ recombination). The logarithm of this ratio is called a lod score. Sums of lod scores exceeding +3 (corresponding to odds of $1000: 1$ ) are usually considered sufficient, or significant, evidence of linkage. A lod score below -2 (odds $1: 100$ ) points to the absence of linkage. ${ }^{14}$

In family A (fig 3) there are $14 \mathrm{nr}$ and $8 \mathrm{r}$ if we assume linkage between the haplotype A2B7 and the ataxia locus: for various values of the recombination fraction $\theta$ negative lod scores result. Assuming linkage between A2BW62 and the 
ataxia locus, there are $12 \mathrm{nr}$ and $9 \mathrm{r}$, also resulting in negative lod scores for various values of $\theta$. In family $B$ III -3 proved to be a recombinant between the A and B loci of the HLA system. We furthermore consider III-6 too young (age 18) to be affected if she were to carry the abnormal gene; consequently only 8 individuals were included in table 2. Thus, in family B (fig 4) assuming linkage with the HLA haplotype A3B7Dr2, this results in a ratio of $5 \mathrm{nr}$ to $3 \mathrm{r}$. Accepting, on the other hand linkage with A29 BW45 Cw6 Dr4 the calculation leads to $6 \mathrm{nr}$ to $2 \mathrm{r}$. The results of these calculations with the corresponding lod scores are summarised in table 2 . In both families the lod scores for various values of $\theta$, therefore, gave no evidence for linkage between the HLA loci and ataxia gene.

The detailed results of typing of the serum markers and red cell enzymes are given in tables 3 and 4. (Since polymorphism for E2 and TF was not present in both families, all individuals being respectively $\mathrm{C5}^{-}$and TF-C, they are not included in table 3. The same holds true for DIAB and SOD, all individuals being DIAB $_{1}$ and SOD $_{1}$.) There is no evidence of linkage between these genetic markers and the ataxia locus. The marker glyoxalase (GLO) is known to be on chromosome 6, the locus being situated between HLA A and PGM3 ${ }^{15-17}$ In family $A$ this marker was not informative. In family B we considered two possibilities. If we assume linkage of the ataxia locus with $\mathrm{GLO}_{1}$ there are $7 \mathrm{nr}$ and $2 \mathrm{r}$, and if we assume linkage with $\mathrm{GLO}_{2}$, there are $4 \mathrm{nr}$ and $5 \mathrm{r}$; close linkage can therefore be excluded. Detailed results of the typing of bloodgroups and immunoglobulins are presented in the tables 5 and 6.

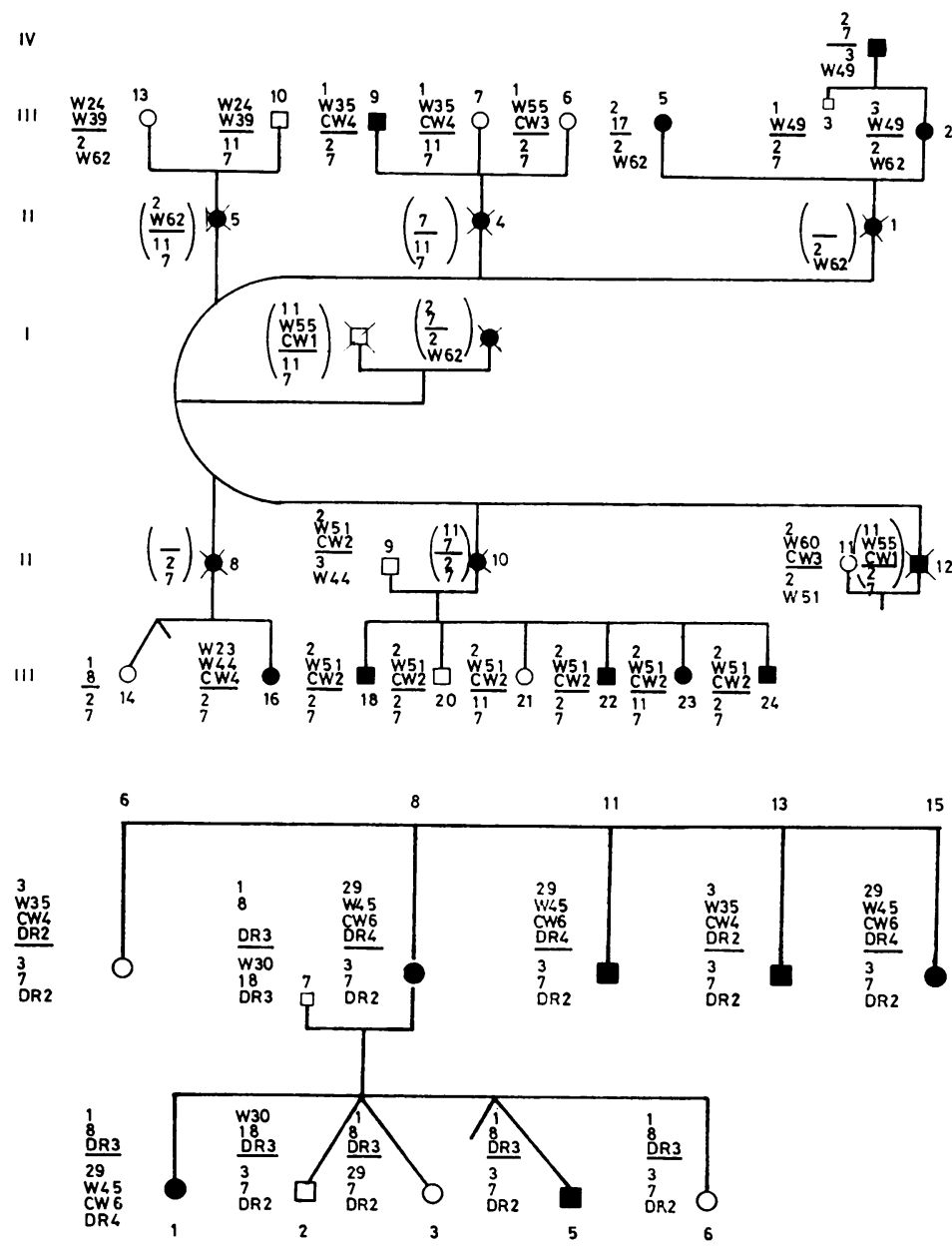

Fig 3 Pedigree of family $A$ showing the HLA haplotypes. In brackets: haplotypes reconstituted from children and spouses.

Fig 4 Pedigree of family $B$ showing the HLA haplotypes. 
Table 2 Estimation of lod scores for various values of the recombination fraction $\theta$

\begin{tabular}{|c|c|c|c|c|c|c|c|c|c|c|c|}
\hline Family $A$ & $\theta$ & & & & & & $\theta$ & & & & \\
\hline & 0.01 & $0 \cdot 1$ & 0.2 & 0.3 & 0.4 & & 0.01 & 0.1 & 0.2 & 0.3 & 0.4 \\
\hline \multirow[t]{2}{*}{$\begin{array}{c}14 \mathrm{nr} \\
8 \mathrm{r}\end{array}$} & $\begin{array}{c}4 \cdot 1 \\
-13.6\end{array}$ & $\begin{array}{r}3.6 \\
-5.6\end{array}$ & $\begin{array}{r}2 \cdot 8 \\
-3 \cdot 2\end{array}$ & $\begin{array}{r}2.0 \\
-1.8\end{array}$ & $\begin{array}{r}1 \cdot 1 \\
-0.8\end{array}$ & $\begin{array}{c}12 \mathrm{nr} \\
9\end{array}$ & $\begin{array}{c}3 \cdot 6 \\
-15 \cdot 3\end{array}$ & $\begin{array}{r}3 \cdot 1 \\
-6 \cdot 3\end{array}$ & $\begin{array}{r}2 \cdot 4 \\
-3 \cdot 6\end{array}$ & $\begin{array}{r}1 \cdot 7 \\
-2 \cdot 0\end{array}$ & $\begin{array}{r}0.9 \\
-0.9\end{array}$ \\
\hline & $-9 \cdot 5$ & $-2 \cdot 0$ & -0.4 & $0 \cdot 2$ & $0 \cdot 3$ & & $-11 \cdot 7$ & $-3 \cdot 2$ & $-1 \cdot 2$ & -0.3 & 0 \\
\hline Family $B$ & $\begin{array}{ll}\theta & \\
0.01\end{array}$ & 0.1 & 0.2 & 0.3 & 0.4 & & $\begin{array}{ll}\theta & \\
& 0.01\end{array}$ & $0 \cdot 1$ & 0.2 & 0.3 & 0.4 \\
\hline \multirow[t]{2}{*}{$\begin{array}{l}5 \mathrm{nr} \\
3 \mathrm{r}\end{array}$} & $\begin{array}{r}1 \cdot 5 \\
-8 \cdot 5\end{array}$ & $\begin{array}{r}1 \cdot 3 \\
-3 \cdot 5\end{array}$ & $\begin{array}{r}1.0 \\
-2.0\end{array}$ & $\begin{array}{r}0.7 \\
-1.1\end{array}$ & $\begin{array}{r}0.4 \\
-0.5\end{array}$ & $\begin{array}{l}6 \mathrm{nr} \\
2 \mathrm{r}\end{array}$ & $\begin{array}{r}1 \cdot 8 \\
-3.4\end{array}$ & $\begin{array}{r}1.5 \\
-1.4\end{array}$ & $\begin{array}{r}1.2 \\
-0.8\end{array}$ & $\begin{array}{r}0.9 \\
-0.4\end{array}$ & $\begin{array}{r}0.5 \\
-0.2\end{array}$ \\
\hline & $-6 \cdot 0$ & $-2 \cdot 2$ & -1.0 & -0.4 & -0.1 & & -1.6 & $0 \cdot 1$ & 0.4 & 0.5 & 0.3 \\
\hline
\end{tabular}

$\mathrm{nr}=$ non-recombinants $; \mathrm{r}=$ recombinants

Table 3 Genetic markers in family A: serum groups and erythrocyte enzymes

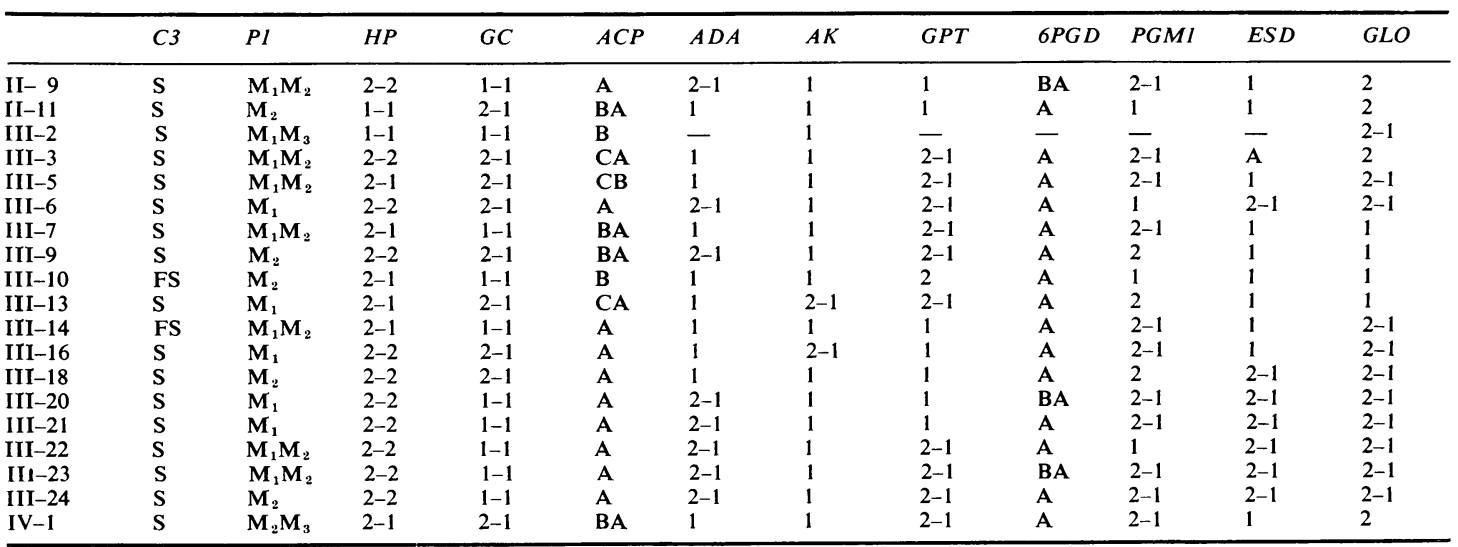

Table 4 Genetic markers in family B: serum groups and erythrocyte enzymes

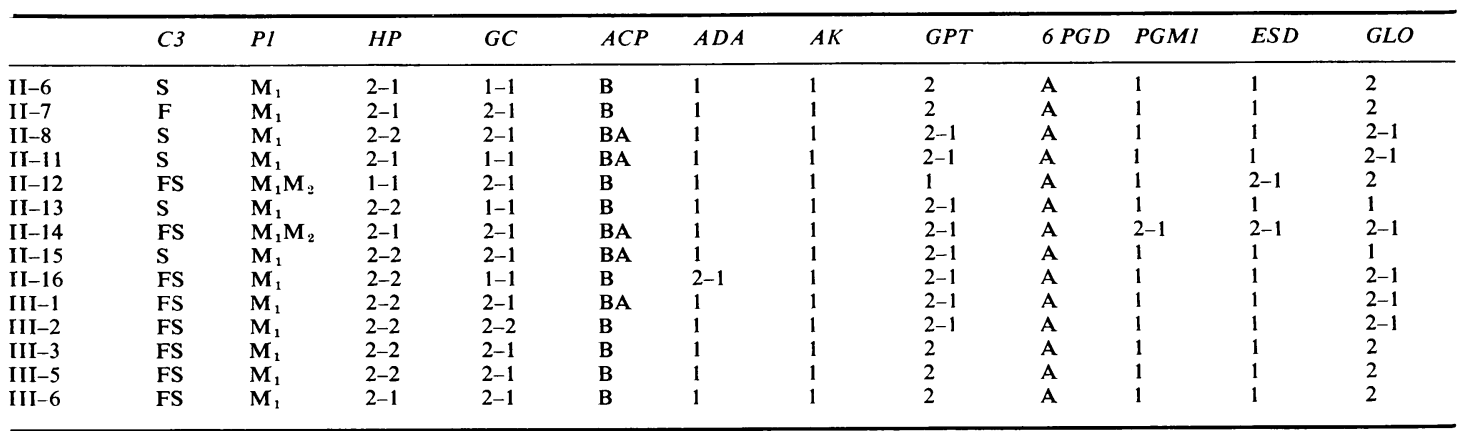

Concerning the $\mathrm{ABO}$ and Rhesus blood group systems there is a sufficient number of recombinants to exclude close linkage. The other marker genes gave too little information to make a decision about linkage possible.

\section{Discussion}

This investigation of two families failed to yield evidence for linkage of the ataxia locus on chromosome 6 on the basis of HLA typing. These 
Table 5 Genetic markers in family A: blood groups and immunoglobulins

\begin{tabular}{|c|c|}
\hline II-9 & $\begin{array}{l}\mathrm{Al} \beta \mathrm{MNS}+\mathrm{Pl}-\mathrm{Lu}(\mathrm{a}-) \mathrm{CcDEe} \mathrm{K}-\mathrm{Fy}(\mathrm{a}+) \mathrm{JK}(\mathrm{a}+) \\
\mathrm{Gm}(\mathrm{z}+\mathrm{a}+\mathrm{x}+\mathrm{f}+\mathrm{N}+\mathrm{g}+\mathrm{b}+) \mathrm{A} 2 \mathrm{~m}(1+, 2-) \mathrm{Km}(1-, 3+)\end{array}$ \\
\hline II-11 & $\begin{array}{l}\mathrm{O} a \beta \mathrm{MNS}-\mathrm{Pl}+\mathrm{Lu}(\mathrm{a}-) \mathrm{ccDEe} \mathrm{K}-\mathrm{Fy}(\mathrm{a}+) \mathrm{JK}(\mathrm{a}+) \\
\mathrm{Gm}(\mathrm{z}+\mathrm{a}+\mathrm{x}-\mathrm{f}+\mathrm{N}+\mathrm{g}+\mathrm{b}+) \mathrm{A} 2 \mathrm{~m}(1+, 2-) \mathrm{Km}(1-, 3+)\end{array}$ \\
\hline III-2 & $\begin{array}{l}\mathrm{Al} \beta \mathrm{MNS}-\mathrm{Pl}+\mathrm{Lu}(\mathrm{a}-) \mathrm{CcD} \text { ee } \mathrm{K}-\mathrm{Fy}(\mathrm{a}-) \mathrm{JK}(\mathrm{a}-) \\
\mathrm{Gm}(\mathrm{z}+\mathrm{a}+\mathrm{x}-\mathrm{f}+\mathrm{N}-\mathrm{g}+\mathrm{b}+) \mathrm{A} 2 \mathrm{~m}(1+, 2-) \mathrm{Km}(1-, 3+)\end{array}$ \\
\hline III-3 & $\begin{array}{l}\mathrm{O} a \beta \mathrm{NNS}-\mathrm{Pl}+\mathrm{Lu}(\mathrm{a}-) \text { ccdee } \mathrm{K}-\mathrm{Fy}(\mathrm{a}+) \mathrm{JK}(\mathrm{a}+) \\
\mathrm{Gm}(\mathrm{z}-\mathrm{a}-\mathrm{x}-\mathrm{f}+\mathrm{N}+\mathrm{g}-\mathrm{b}+) \mathrm{A} 2 \mathrm{~m}(1+, 2-) \mathrm{Km}(1+, 3+)\end{array}$ \\
\hline III-5 & $\begin{array}{l}\mathrm{Al} \beta \mathrm{MNS}-\mathrm{Pl}+\mathrm{Lu}(\mathrm{a}-) \mathrm{CcDee} \mathrm{K}-\mathrm{Fy}(\mathrm{a}-) \mathrm{JK}(\mathrm{a}+) \\
\mathrm{Gm}(\mathrm{z}+\mathrm{a}+\mathrm{x}-\mathrm{f}+\mathrm{N}-\mathrm{g}+\mathrm{b}+) \mathrm{A} 2 \mathrm{~m}(1+, 2-) \mathrm{Km}(1-, 3+)\end{array}$ \\
\hline III-6 & $\begin{array}{l}\text { Ba MMS }-\mathrm{Pl}+\mathrm{Lu}(\mathrm{a}-) \mathrm{ccDEe} \mathrm{K}-\mathrm{Fy}(\mathrm{a}+) \mathrm{JK}(\mathrm{a}+) \\
\mathrm{Gm}(\mathrm{z}-\mathrm{z}-\mathrm{x}-\mathrm{f}+\mathrm{N}+\mathrm{g}-\mathrm{b}+) \mathrm{A} 2 \mathrm{~m}(1+, 2-) \mathrm{Km}(1-, 3+)\end{array}$ \\
\hline III-7 & $\begin{array}{l}\mathbf{L S}+\mathbf{P l}+\mathbf{L u}(\mathrm{a}-(\mathrm{ccd} \\
\mathrm{a}-\mathrm{x}-\mathrm{f}+\mathrm{N}+\mathrm{g}-\mathrm{b}+)\end{array}$ \\
\hline III-9 & $a-x-f+N+g-b-$ \\
\hline III-10 & $\begin{array}{l}-) \\
-, 3+)\end{array}$ \\
\hline III-13 & $\begin{array}{l}\mathbf{S}-\mathbf{P l}+\mathbf{L u}(\mathrm{a}-) \mathrm{cc} \\
-\mathrm{x}-\mathrm{f}+\mathrm{N}-\mathrm{g}-\mathrm{b}+\end{array}$ \\
\hline III-14 & $\begin{array}{l}\mathrm{MS}+\mathrm{Pl}-\mathbf{L u}(\mathrm{a}-) \mathrm{ccI} \\
-\mathrm{a}-\mathrm{x}-\mathrm{f}+\mathrm{N}-\mathrm{g}-\mathrm{b}+)\end{array}$ \\
\hline III-16 & $\begin{array}{l}a+) \\
(-, 3+)\end{array}$ \\
\hline III-18 & $\begin{array}{l}\mathrm{Pl}-\mathrm{Lu}(\mathrm{a}-) \mathrm{CcD} \\
-\mathrm{x}-\mathrm{f}+\mathrm{N}+\mathrm{g}-\mathrm{b}\end{array}$ \\
\hline III-20 & $\begin{array}{l}\mathrm{Al} \beta \mathrm{MNS}+\mathrm{Pl}-\mathrm{Lu}(\mathrm{a}-) \mathrm{ccl} \\
\mathrm{Gm}(\mathrm{z}+\mathrm{a}+\mathrm{x}+\mathrm{f}+\mathrm{N}+\mathrm{g}+\mathrm{b}+\end{array}$ \\
\hline III-21 & $\begin{array}{l}\text { AlB MMS }+P 1-L u(a-) \text { ccDEE } K-\text { Fy(a-) JK( }(a+) \\
\text { Gm }(z+a+x+f+N+g+b+) \text { A2m }(1+.2-) \mathrm{Km}(1-, 3+)\end{array}$ \\
\hline III-22 & $\begin{array}{l}\text { AlB MNS }+\mathrm{Pl}-\mathrm{Lu}(\mathrm{a}-) \mathrm{CcDEe} \mathrm{K}-\mathrm{Fy}(\mathrm{a}-) \mathrm{JK}(\mathrm{a}+) \\
\mathrm{Gm}(\mathrm{z}+\mathrm{a}+\mathrm{x}+\mathrm{f}+\mathrm{N}+\mathrm{g}+\mathrm{b}+) \mathrm{A} 2 \mathrm{~m}(1+, 2-) \mathrm{Km}(1-, 3+)\end{array}$ \\
\hline III-23 & $\begin{array}{l}\mathrm{Al} \beta \mathrm{MNS}+\mathrm{Pl}-\mathrm{Lu}(\mathrm{a}-) \operatorname{ccDEE} \mathrm{K}-\mathrm{Fy}(\mathrm{a}-) \\
\mathrm{Gm}(\mathrm{z}+\mathrm{a}+\mathrm{x}+\mathrm{f}+\mathrm{N}+\mathrm{g}+\mathrm{b}+) \mathrm{A} 2 \mathrm{~m}(1+, 2-) \mathrm{K}\end{array}$ \\
\hline III-24 & $\begin{array}{l}\mathrm{Al} \beta \mathrm{MNS}+\mathrm{Pl}-\mathrm{Lu}(\mathrm{a}-) \text { ccDEE K-Fy8a+) JK( }(\mathrm{a}+) \\
\mathrm{Gm}(\mathrm{z}+\mathrm{a}+\mathrm{x}+\mathrm{f}+\mathrm{N}+\mathrm{g}+\mathrm{b}+) \mathrm{A} 2 \mathrm{~m}(1+, 2-) \mathrm{Km}(1-, 3+)\end{array}$ \\
\hline IV-1 & $\begin{array}{l}\mathrm{O} \alpha \beta \mathrm{MNS}-\mathrm{Pl}+\mathrm{Lu}(\mathrm{a}-) \mathrm{ccdee} \mathrm{K}-\mathrm{Fy}(\mathrm{a}+) \mathrm{JK}(\mathrm{a}-) \\
\mathrm{Gm}(\mathrm{z}-\mathrm{a}-\mathrm{x}-\mathrm{f}+\mathrm{N}+\mathrm{g}-\mathrm{b}+) \mathrm{A} 2 \mathrm{~m}(1+, 2-) \mathrm{Km}(1+, 3+)\end{array}$ \\
\hline
\end{tabular}

findings are in agreement with the results obtained by Wastiaux et $a l^{7}$ and Koeppen et al. ${ }^{8}$ Yakura's ${ }^{1}$ suggestion for HLA linkage with the ataxia locus was based on insufficient data consisting of three affected sibs out of five in one family. The findings of Jackson et $a l^{2}$ appear to be in favour of linkage of the HLA and ataxia loci as a lod score of 3.15 at a recombination fraction of $0 \cdot 12$ was calculated in the family they investigated. However, HLA typing was performed only in affected individuals so that the frequency of the HLA types remained unknown in non-affected sibs. This may well have resulted in erroneous results. Möller et $\mathrm{al}^{3}$ in describing the results of HLA typing in three different families which each showed various additional symptoms along with ataxia (sensory polyneuropathy with bladder disturbances; mental retardation; vegetative symptoms) found varying results. In their first family the two affected sibs had the
Table 6 Genetic markers in family B: blood groups and immunoglobulins

\begin{tabular}{|c|c|}
\hline III-6 & $\begin{array}{l}\mathrm{Al} \beta \mathrm{MNS}-\mathrm{Pl}+\mathrm{Lu}(\mathrm{a}+) \text { ccdee } \mathrm{K}-\mathrm{Fy}(\mathrm{a}+) \\
\mathrm{Gm}(\mathrm{z}-\mathrm{a}-\mathrm{x}-\mathrm{f}+\mathrm{N}+\mathrm{g}-\mathrm{b}+) \mathrm{A} 2 \mathrm{~m}(1+, 2-) \mathrm{Km}(1+, 3+)\end{array}$ \\
\hline II-7 & $\begin{array}{l}\mathrm{Al} \beta \mathrm{MNS}+\mathrm{Pl}+\mathrm{Lu}(\mathrm{a}-) \mathrm{ccdee} \mathrm{K}-\mathrm{Fy}(\mathrm{a}-) \\
\mathrm{Gm}(\mathrm{z}+\mathrm{a}+\mathrm{x}-\mathrm{f}+\mathrm{N}-\mathrm{g}+\mathrm{b}+) \mathrm{A} 2 \mathrm{~m}(1+, 2-) \mathrm{Km}(1-, 3+)\end{array}$ \\
\hline II-8 & $\begin{array}{l}\text { B } a \mathrm{MNS}-\mathrm{Pl}+\mathrm{Lu}(\mathrm{a}-) \text { ccdee } \mathrm{K}-\mathrm{Fy}(\mathrm{a}+) \\
\mathrm{Gm}(\mathrm{z}+\mathrm{a}+\mathrm{x}+\mathrm{f}+\mathrm{N}+\mathrm{g}+\mathrm{b}+) \mathrm{A} 2 \mathrm{~m}(1+, 2-) \mathrm{Km}(1+, 3+)\end{array}$ \\
\hline II-1 I & $\begin{array}{l}\text { Ba } a N S-P 1-L u(a+) \text { CcDee } K-F y(a-) \\
\operatorname{Gm}(z-a-x-f+N+g-b+) A 2 m(1+, 2-) K m(1-, 3+)\end{array}$ \\
\hline II-12 & $\begin{array}{l}\mathrm{O} a \beta \mathrm{MNS}-\mathrm{Pl}-\mathrm{Lu}(\mathrm{a}-) \mathrm{ccD} \\
\mathrm{Gm}(\mathrm{z}+\mathrm{a}+\mathrm{x}+\mathrm{f}+\mathrm{N}-\mathrm{g}+\mathrm{b}+)\end{array}$ \\
\hline II-13 & $\mathrm{m}(1+, 2-) \mathrm{Ky}(\mathrm{a}-) \mathrm{m}(1+, 3+)$ \\
\hline II -14 & $\begin{array}{l}-\mathrm{Fy}(\mathrm{a}-) \\
\mathrm{m}(1+, 2+) \mathrm{Km}(1+, 3+)\end{array}$ \\
\hline II-15 & +) $\mathrm{Km}(1-, 3+)$ \\
\hline II-16 & $\begin{array}{l}\mathrm{K}-\mathrm{Fy}(\mathrm{a}+) \\
\mathrm{n}(1+, 2-) \mathrm{Km}(1-, 3+)\end{array}$ \\
\hline III-1 & $\begin{array}{l}\mathrm{O} a \beta \mathrm{NNS}-\mathrm{Pl}+\mathrm{Lu}(\mathrm{a}-) \mathrm{ccdee} \mathrm{K}-\mathrm{Fy}(\mathrm{a}+) \\
\mathrm{Gm}(\mathrm{z}-\mathrm{a}-\mathrm{x}-\mathrm{f}+\mathrm{N}+\mathrm{g}-\mathrm{b}+) \mathrm{A} 2 \mathrm{~m}(1+, 2-) \mathrm{Km}(1-, 3+)\end{array}$ \\
\hline IIl-2 & $\begin{array}{l}\mathrm{B} a \mathrm{MNS}+\mathrm{Pl}+\mathrm{Lu}(\mathrm{a}-) \text { ccdee } \mathrm{K}-\mathrm{Fy}(\mathrm{a}-) \\
\mathrm{Gm}(\mathrm{z}-\mathrm{a}-\mathrm{x}-\mathrm{f}+\mathrm{N}+\mathrm{g}-\mathrm{b}+) \mathrm{A} 2 \mathrm{~m}(1+, 2-) \mathrm{Km}(1-, 3+)\end{array}$ \\
\hline I1I-3 & $\begin{array}{l}\mathrm{Al} \beta \mathrm{MNS}-\mathrm{Pl}+\mathrm{Lu}(\mathrm{a}-) \mathrm{ccdee} \mathrm{K}-\mathrm{Fy}(\mathrm{a}+) \\
\mathrm{Gm}(\mathrm{z}+\mathrm{a}+\mathrm{x}+\mathrm{f}-\mathrm{N}-\mathrm{g}+\mathrm{b}-) \mathrm{A} 2 \mathrm{~m}(1+, 2-) \mathrm{Km}(1-, 3+)\end{array}$ \\
\hline III-5 & $\begin{array}{l}\mathrm{K}-\mathrm{Fy}(\mathrm{a}-) \\
2 \mathrm{~m}(1+, 2-) \mathrm{Km}(1-, 3+)\end{array}$ \\
\hline III-6 & $\begin{array}{l}\mathrm{B} a \mathrm{MNS}-\mathrm{Pl}+\mathrm{Lu}(\mathrm{a}-) \mathrm{ccdee} \mathrm{K}-\mathrm{Fy}(\mathrm{a}-) \\
\mathrm{Gm}(\mathrm{z}+\mathrm{a}+\mathrm{x}+\mathrm{f}-\mathrm{N}-\mathrm{g}+\mathrm{b}+) \mathrm{A} 2 \mathrm{~m}(1+, 2-) \mathrm{Km}(1-, 3+)\end{array}$ \\
\hline
\end{tabular}

same HLA haplotypes from the affected father, the unaffected sib inherited the other haplotype from him. In their second family the same haplotype was found in two affected and two unaffected sibs in the second generation, in generation III it was found in three affected and two unaffected sibs. In their third family too few individuals were typed to draw any conclusions. These findings can hardly be interpreted as being strongly in favour of linkage. Nino's results ${ }^{4}$ showing a maximum lod score of 1.56 at a recombination fraction of 0.29 cannot be regarded as sufficient evidence for linkage, no more than Pedersen'si results showing a maximum lod score of 0.914 at a recombination fraction of $0 \cdot 20$. There seems little reason to use genetic heterogeneity as an explanation for these varying and uncertain results.

In view of both our present findings and the controversial results of other investigators, one can conclude that linkage studies have failed to be useful for early diagnosis or counselling in families with dominantly inherited ataxia. In our study the distribution frequency of the different HLA types in the population was not taken into account, but the negative values of the lod scores are sufficient evidence against close linkage between the HLA and ataxia loci. 
We are indebted to the Dutch genetic marker phenotyping group for their friendly co-operation. The genetic typing was made possible by financial support of the Praeventiefonds, The Hague.

\section{References}

1 Yakura H, Wakisaka A, Fujimoto S, Itakura K. Hereditary ataxia and HLA genotypes. $N$ Engl $J$ Med 1974; 291:154-5.

2 Jackson JF, Currier RD, Terasaki PI, Morton NE. Spinocerebellar ataxia and HLA linkage. $N$ Engl J Med 1977; 296:1138-41.

3 Möller E, Hindfelt B, Olsen JE. HLA-determination in families with hereditary ataxia. Tissue Antigens 1978; 12:357-66.

4 Nino HE, Noreen HJ, Yunis EJ, Resch JA, Dubey DP. A family with hereditary ataxia: results of HLA typing. Neurology (Minneap) 1978; 28:353.

5 Nino HE, Noreen HJ, Dubley DP, et al. A family with hereditary ataxia: HLA typing. Neurology (Minneap) 1980; 30:12-20.

6 Pedersen L, Platz P, Ryder LR, Lamm LU, Dissing J. A linkage study of hereditary ataxias and related disorders. Hum Genet 1980; 54: 371-83.

7 Wastiaux JP, Lamoureux G, Bouchard JP, Durivage A, Barbeau C, Barbeau A. HLA and complement typing in olivopontocerebellar atrophy. Can J Neurol Sci 1978; 5:75-81.

8 Koeppen AH, Goedde HW, Hirth L, Benkmann
HG, Hiller C. Genetic linkage in hereditary ataxia. Lancet 1970; I:92-3.

9 Schut JW. Hereditary ataxia. Clinical study through six generations. Arch Neur Psych (Chicago) 1950; 63:535-68.

10 Schut JW, Book JA. Hereditary ataxia. Arch Neur Psych (Chicago) 1953; 70:169-79.

11 Konigsmark BW, Weiner LP. The olivopontocerebellar atrophies: a review. Medicine (Baltimore) $1970 ; 49: 227-42$.

12 Hoogenraad TU. Een zeldzame degeneratieve ziekte van het zenuwstelsel. Ned T Geneesk 1966; 110:2020

13 Maynard-Smith S, Penrose LS, Smith CAB. Mathematical tables for research workers in human genetics. London: J \& A Churchill, 1961.

14 Went LN, Volkers WS. Genetic Linkage. In: Chase TN, et al, ed. Advances in Neurology, vol 23, 37-42. New York: Raven Press, 1979.

15 Meera Khan P. The locus glyoxalase I (GLO) is between HLA-A and PGM $_{3}$ on chromosome 6 of man. Baltimore Conference 1975: Third International Workshop on Human Gene Mapping. Birth defects: original article series, $X I I, 7$. New York: The National Foundation, 1976.

16 Meere Khan P, Doppert BA. Rapid detection of glyoxalase I (GLO) in cellulose acetate gel and the distribution of GLO variants in a Dutch population. Hum Genet 1976; 34:53-6.

17 Bruining $\mathrm{MH}$, van de Berg-Loonen EM, Bernini LF, et al. Localization of HLA on the short arm of chromosome 6. Hum Genet 1977; 37: 131-9. 